\title{
Spatial hotspot patterns of a home burglary in Penang
}

\author{
Mohd Norarshad Nordin, Tarmiji Masron, Nur Emyliana Yunos, Norita Jubit \\ Centre for Spatially Integrated Digital and Humanities, Faculty of Social Sciences and Humanities, \\ Universiti Malaysia Sarawak \\ Correspondence: Tarmiji Masron (email: mtarmiji@unimas.my)
}

Received: 11 February 2020; Accepted: 11 May 2020; Published: 30 May 2020

\begin{abstract}
This study is based on property crime cases in the Northeast of Penang using GIS application for crime prevention. Studies based on the spatial elements showed that GIS application was able to reduce the crime issues. The purpose of this study is to identify the hotspots of home burglary based on time incident in Penang using GIS spatial statistics. Based on the report of house burglary cases from 2013 until 2015. Getis Ord Gi* was used to identify the high-risk areas of home burglary cases based on z-scores and p-values. The analysis shows that the areas of the hot spot cases of home burglary are the same for night and day incidents. In 2013, the hot spot areas at night were 7 areas, and during the day only 1 incident was identified. Hot spot increases in 2014 to 9 areas for nighttime incidents while daytime events also increased to 10 areas. While 2015 showed that the number of hot spots that occurred at night reduced to 5 areas and daytime incidents also recorded the same number of hot spots during the night incidents. Hot spot areas also frequently identified in urban areas and high population density such as Jelutong, Dato Keramat, Tanjung Tokong dan Sungai Nibong. The result showed that hotspots of home burglary are more concentrated in residential areas with good road network accessibility. This study can assist the authorities such as the Royal Malaysia Police (RPM) in preventing and reducing the crime index by using GIS applications.
\end{abstract}

Keywords: burglary, GIS, z-score, p-value, hotspots, sector, police station

\section{Introduction}

Due to rapid urbanization and development, Malaysia shows increasing numbers of problemrelated to crime. The issue of criminal conduct is not a new subject to address, but the escalating crime rates have raised concern to society, especially in the media coverage and the academics of various disciplines. The increase in crime revealed that it was associated with the rapid development of a city (Ahmad Tarmizi et al., 2017). The crime index measurement implement today is no longer relevant to be used as a Key Performance Indicator (KPI).

Crime incidents are often associated with high-risk urban areas compared to other areas. It is undeniable facts due to the exponential growth of total populations and living 
demands which leads to increase crime cases (Mohamed, 2019). According to the Department of Statistics Malaysia (2015), documented crimes are divided into two types: violent crime and property crime. Violent crimes comprised of murder, rape, armed robbery, unarmed robbery, and criminal mischief, while property crimes include burglary, motor vehicle theft, motorcycle theft, robbery, and others.

According to the Department of Statistics Malaysia (2017), property crime cases by states show that Penang is among the top of the list with the highest number of property crimes. In addition, the burglary cases are one of the main issues to address (Table 1) which also stated as one of six sectors to focus on National Key Result Areas (NKRA) in reducing the crimes.

The house environments and security are in jeopardy due to the increasing number of burglary cases. The Crime Prevention sector in NKRA continues to work to reduce the number of burglaries, as the lawbreakers are targeting public housing. The home burglary issues have been taken seriously by the authorities especially the RPM. It also has been included in the NKRA's initiative in reducing crime also in Government Transformation Program (GTP) annual reports (Prime Minister's Department of Malaysia, 2014).

Table 1. Property crimes according to states

\begin{tabular}{lrrrrrr}
\hline States & $\mathbf{2 0 1 1}$ & $\mathbf{2 0 1 2}$ & $\mathbf{2 0 1 3}$ & $\mathbf{2 0 1 4}$ & $\mathbf{2 0 1 5}$ & $\mathbf{2 0 1 6}$ \\
\hline Selangor & 36,161 & 32,333 & 34,407 & 28,763 & 25,964 & 24,612 \\
F.T. Kuala Lumpur & 18,610 & 16,733 & 15,206 & 13,342 & 12,038 & 12,950 \\
Johor & 16,542 & 15,226 & 13,866 & 12,149 & 11,067 & 10,121 \\
Kedah & 9,032 & 8,560 & 7,274 & 6,692 & 6,506 & 6,201 \\
Sarawak & 5,976 & 9,296 & 8,166 & 6,664 & 6,377 & 5,873 \\
Penang & 8,346 & 7,116 & 6,540 & 6,277 & 5,486 & 5,078 \\
Perak & 7,784 & 6,627 & 5,822 & 5,358 & 4,940 & 4,546 \\
Sabah ${ }^{\text {b }}$ & 2,311 & 5,043 & 4,644 & 4,388 & 4,218 & 4,528 \\
Kelantan & 5,329 & 5,236 & 4,998 & 4,788 & 4,387 & 4,005 \\
Negeri Sembilan & 4,455 & 4,863 & 4,501 & 4,058 & 3,508 & 3,390 \\
Pahang & 5,234 & 4,777 & 4,475 & 4,354 & 3,580 & 3,126 \\
Melaka & 4,208 & 4,017 & 3,414 & 2,870 & 2,362 & 2,510 \\
Terengganu & 3,398 & 3,076 & 3,163 & 2,754 & 2,282 & 2,087 \\
Perlis & 971 & 816 & 676 & 662 & 599 & 546 \\
F.T. Putrajaya & 0 & 0 & 333 & 266 & 236 & 263 \\
F.T. Labuan & 0 & 0 & 202 & 184 & 185 & 192 \\
\hline Sol De.
\end{tabular}

Source: Department of Statistics Malaysia, 2017

One case of property crimes in Penang is reported every 52.6 minutes and violent crimes occur every 8 hours. Besides, vehicle theft cases are reported every day where a motorcycle is stolen every 3 hours and one robbery occurs every 11 hours. Crime cases in Penang show that property crimes are higher than violent crimes. The total number of cases collected from 2011 to 2016 showed that violent crimes recorded 15,010 cases while property crimes recorded 38,843 cases. The number of home burglary cases from 2011 to 2016 registered 6,690 cases. Table 2 show that the home burglary cases show a decline from 2011 to 2016 (Department of Statistics Malaysia, 2017). 
Table 2. Type of crimes in Penang

\begin{tabular}{lrrrrrr}
\hline Year & $\mathbf{2 0 1 1}$ & $\mathbf{2 0 1 2}$ & $\mathbf{2 0 1 3}$ & $\mathbf{2 0 1 4}$ & $\mathbf{2 0 1 5}$ & $\mathbf{2 0 1 6}$ \\
\hline Violent & Crimes & & & & \\
Murder & 31 & 47 & 36 & 53 & 32 & 28 \\
Rape & 146 & 123 & 118 & 93 & 77 & 65 \\
Grouping Armed Robbery & 12 & 7 & 6 & 4 & 5 & 2 \\
Grouping Unarmed Robbery & 660 & 586 & 729 & 544 & 573 & 406 \\
Armed Robbery & 1 & 2 & 0 & 1 & 2 & 1 \\
Unarmed Robbery & 204 & 74 & 170 & 191 & 199 & 224 \\
Criminal Mischief & 358 & 344 & 337 & 328 & 324 & 312 \\
Total & 1,412 & 1,283 & 1,396 & 1,214 & 1,212 & 1,038 \\
& Property Crime & & & & \\
Theft & 1,907 & 1,274 & 1,089 & 1131 & 969 & 1,010 \\
Motor Vehicle Theft & 647 & 671 & 716 & 640 & 494 & 449 \\
Van, Lorry, Truck Theft & 3,776 & 3,601 & 3,365 & 2,969 & 2,488 & 2,401 \\
Motorcycle Theft & 142 & 168 & 211 & 166 & 154 & 110 \\
Robbery & 198 & 275 & 165 & 245 & 231 & 191 \\
Burglary & 1,676 & 1,127 & 994 & 1,126 & 1,150 & 917 \\
Total & 8,346 & 7,116 & 6,540 & 6,277 & 5,486 & 5,078 \\
\hline Solat & & & & & &
\end{tabular}

Source: Department of Statistics Malaysia, 2017

However, the fear of crime still exists in society. Statistics from January to August 27, 2019, show that index crime rates have dropped $7.2 \%$ but there have been small increases in Penang, Sarawak, and Terengganu (BERNAMA, 2019). From 2011 to 2016, home burglary recorded the third-highest incidence in Malaysia, with a total of 6,990 cases. PDRM reports found that home burglary was reported to occur in urban areas (Siti Norul Huda et al., 2018).

Table 3. Home burglary crimes statistics according to states in 2011-2016

\begin{tabular}{lrrrrrrr}
\hline States & $\mathbf{2 0 1 1}$ & $\mathbf{2 0 1 2}$ & $\mathbf{2 0 1 3}$ & $\mathbf{2 0 1 4}$ & $\mathbf{2 0 1 5}$ & $\mathbf{2 0 1 6}$ & \multicolumn{1}{c}{ Total } \\
\hline Selangor & 8,422 & 6,337 & 7,742 & 6,184 & 5,805 & 5,497 & 39,987 \\
F.T. Kuala Lumpur ${ }^{\mathrm{c}}$ & 3,480 & 2,838 & 2,425 & 2,118 & 1,857 & 1,820 & 14,538 \\
Johor & 2,598 & 2,219 & 1,798 & 1,603 & 1,440 & 1,475 & 11,133 \\
Sarawak & 1,996 & 2,627 & 1,597 & 1,402 & 1,273 & 1,540 & 10,435 \\
Kedah $_{\text {Sabah }}^{\mathrm{b}}$ & 1,753 & 1,537 & 1,499 & 1,305 & 1,499 & 1,287 & 8,880 \\
Perak & 615 & 1,717 & 1,599 & 1,377 & 1,494 & 1,693 & 8,495 \\
Negeri Sembilan & 1,640 & 1,470 & 1,176 & 1,201 & 1,134 & 915 & 7,536 \\
Penang & 1,253 & 1,438 & 1,398 & 1,289 & 998 & 1,023 & 7,399 \\
Kelantan & 1,676 & 1,127 & 994 & 1,126 & 1,150 & 917 & 6,990 \\
Pahang & 1,137 & 1,052 & 936 & 1,101 & 893 & 682 & 5,801 \\
Melaka & 1,361 & 1,060 & 873 & 796 & 795 & 719 & 5,604 \\
Terengganu & 1,025 & 820 & 684 & 543 & 445 & 544 & 4,061 \\
Perlis & 852 & 529 & 338 & 419 & 301 & 452 & 2,891 \\
F.T. Putrajaya & 212 & 168 & 111 & 118 & 102 & 85 & 796 \\
F.T. Labuan & 0 & 0 & 81 & 59 & 50 & 47 & 237 \\
\hline
\end{tabular}

Source: Department of Statistics Malaysia, 2017

According to statistics of home-burglary cases in Malaysia for 2011 to 2016, Selangor had the highest number of cases of 39,987 followed by the Federal Territory of Kuala Lumpur 14,538 cases while Johor ranked third with 11,133 cases. However, Penang reportedly ranked 9th in housebreaking cases as shown in Table 3. The current descriptive trend analysis was unable to provide enough information for the authorities to target areas 
with high concentration of crimes. Analytical technique in GIS use spatial element of crimes able to identify the hotspots of home burglary in Penang via location or clusters of crimes. In addition, GIS provide real-time information about what is happening on the surface based on the latitude and longitude value of the crime location through geocoding method that used for analysis. Nearly $90 \%$ of commercial centers face house-breaking and theft cases and this has upraised concerns in Penang society (Ling Ta, 2016).

\section{Literature review}

Mohd Norarshad and Tarmiji (2016) identified high-risk areas of drug abuse among youth in the Northeast district of Penang in 2013 and 2014. The hotspots revealed a declining number from seven sectors classified as hotspot areas in 2013 (Jelutong, Jalan Patani, Kampung Baru and Lebuh Pantai) to three hotspots in 2014 (Lebuh Pantai and Kampung Baru). A high number of drug abuse cases recorded in the city center with rapid development and high population density compared to 2013 hotspot areas.

The study of spatial modeling by Mburu and Bakillah (2016) aimed to identify the spatial interaction of unemployment, homeowners and house prices issues with housebreaking cases in the London Metropolitan city. The method used was the Local Indicator Spatial Autocorrelation (LISA) to identify the clustering of house-breaking cases and the result showed significant clustering of house-breaking cases and unemployment at $p<0.05$. There were three spatial models; spatial lag model-SLM, spatial error model-SEM and spatial Durbin model-SDM to study the spatial interactions.

High unemployment rate had no significant relationship with house-breaking cases due to large numbers of workers and commercial land use. The clustering areas with high density have been identified in central London, which has a high population density and rapid development. In this study, Regression Analysis of Ordinary Least Square (OLS) was used to validate Moran's I for three spatial models and revealed the significant autocorrelation of the three models. This study showed that the spatial interaction between the case of the unemployed, the homeowner and the house price with the house-breaking cases have a significant spatial patterns (Mburu \& Bakillah, 2016).

The Bayesian model was used to study the impact of house-breaking cases on neighborhoods in Wuhan, China. Population density and land use indicate a significant result. These variables were related to the risk of house-breaking cases. Unemployment data were found to be correlated with house-breaking cases while higher education was negatively associated (Liu et al., 2019).

In contrast, the study conducted by Mahfoud et al. (2017) in Dutch used hotspot analysis to study the time interval of house-breaking cases. This study had the advantage of predicting model for house-breaking cases using space-time intervals from January 2008 to April 2014. Each incident contained latitude and longitude, time (month and year). Findings showed that over the last five years (2008-2012), most areas were classified as high-risk of crime covering $97 \%$ of areas consisting of 55 grids (Mahfoud et al., 2017).

According to Luo (2017), the hotspot of house-breaking cases in Chicago was applied using Getis Ord Gi* from 2006 to 2016. There were two spatial scales used; blocks and police bits according to the hours, days and months. Hotspot analysis revealed a change in hotspots pattern for house-breaking cases overtime in Chicago. The results of this study showed that the high-risk house-breaking cases occur in the city center to the south of Chicago. This study can help the police to prevent crime and increased the number of police patrols in identified risk areas. 
Boldt and Borg (2017) had detected statistically significant house-breaking hotspots by year, month, day, and time. Anselin Local Moran's I (LISA) technique revealed the hotspots area and location. Defining significant hotspot areas is important as it was able to plan crime prevention in high-risk house-breaking areas. Besides, house-breaking cases showed a significant value in January 2014 but by October 2014 there were no significant areas. The LISA method also showed the hotspots were linked to the neighborhood boundary.

The forecasting of house-breaking hotspot cases has been carried out in 2014 using two methods, namely the Getis Ord Gi* and Aoristic in the cities of Gothenburg and Karlskrona. The purpose of using both methods was to measure the accuracy of the results. The results showed that the Getis Ord Gi* technique provided statistically significant metrics, z-scores, and statistically significant values. Aoristic has weaknesses as it is only used to estimate time or unspecified cases time. Besides, the aoristic unable to reveal the location of hotspots (Arnesson \& Lewenhagen, 2018).

Norita Jubit et al. (2019) had identified the hotspot areas of property crimes in Kuching, Sarawak. In this study, the 2015-2017 property crime data were analyzed using Getis-Ord Gi* using ArcMap 10.3 application. The finding showed that there were five sectors of the station classified as property crime hotspots within the past two years from 2015 to 2016 involving sectors under the supervision of the Gita, Satok and Sekama police stations. In the following year, 2017 analysis found that hotspots were reduced to four hotspot sectors under the supervision of Gita, Sekama, and Padungan police stations. The result showed that Getis-Ord $\mathrm{Gi}^{*}$ analysis was suitable to identify the hotspots of statistically significant value.

\section{Study area and method}

Penang is located on the Northwest coast of Peninsular Malaysia (Lat 5.414534, Log 100.331094). Georgetown is the capital city of Penang, with the second highest GDP per capita in the country after Kuala Lumpur at RM47,322 in 2016 (Nandri, 2018). This study focused on the Northeast region of Penang as shown in Figure 1. Northeast was chosen as it has the second-highest population density per square kilometer and had experienced rapid urbanization in recent decades (Hedayati et al., 2019). According to property crime statistics, Penang is among the states with higher property crime cases than any other state in Malaysia (Department of Statistics Malaysia, 2017).

In the survey, 583 case reports were obtained from the Criminal Investigation Department (JSJ) of the Northeast District of Penang from 2013 to 2015. There were 13 police stations involved. All cases data were tabulated in MS excel. The incident address of home burglary cases was geocoded to be used in GIS analysis. Getis Ord Gi* method in GIS was used to identify the hot spot of home burglary cases.

Getis Ord Gi* method in GIS application was used to identify statistically significant clustering between high value (hot spot) and low value (cold spot). The hotspot area was determined based on the $\mathrm{z}$-score value. P-value indicates the degree of specificity of the hotspot area. High z-scores and low p-values indicate hotspots, while low-z-scores and low pvalues indicate cold spots. If the $\mathrm{z}$-score value is negative, the p-value is small and indicates no clear grouping in the area as shown in Figure 2. This research contributes to increasing the number of literature on crime data modeling as this study used a smaller unit of analysis (police station sectors) compared to previous studies using the territorial divisions, police stations and districts. 


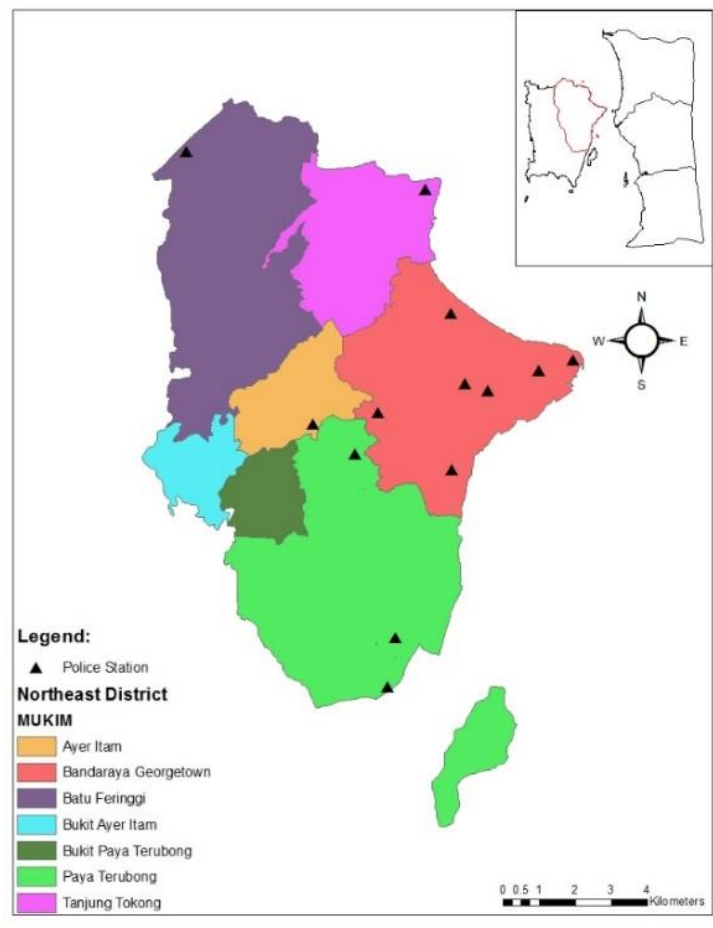

Figure 1. Study area

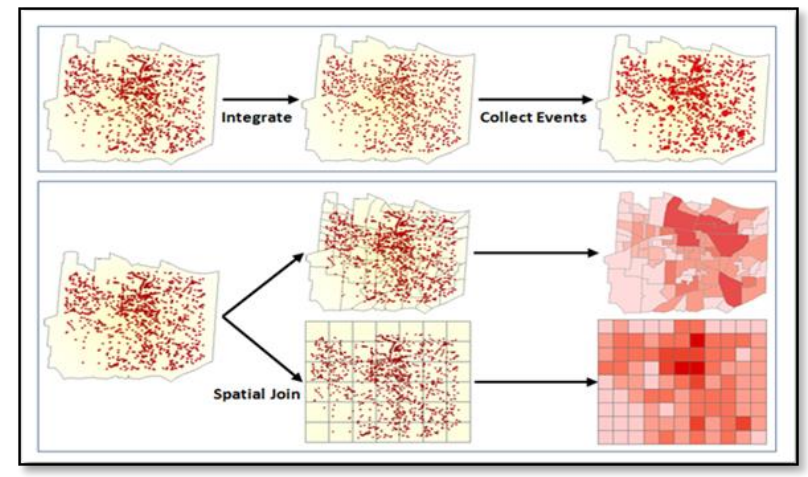

Source: ESRI, 2005

Figure 2. Data aggregation strategy

\section{Result and discussion}

The analysis shows that the police station areas identified as hotspot of the house break-in cases in 2013 are higher at night-time compared to during day-time. Seven sector of hotspots were identified during night-time whereas only one sector in the day-time as shown in Table 4. The hotspots for home burglary at night involved Sungai Nibong, Pulau Tikus, Jelutong, and Dato Keramat Police Station. During day-time, only the Jelutong Police Station sector was involved. Figure 3 shows the hotspot cases of home burglaries according to the day-time and night-time of 2013 incidents.

Sungai Nibong (Sector A), Pulau Tikus (Sector 2) and Jelutong Police Station (Sector 26) recorded the highest rates of house-break-in hotspot sectors. These areas show Gi_Bin = 3 which is a highly significant hotspot. Sector A (Sungai Nibong) had the highest z-score of 3.926, while Sector 2 and Sector 26 recorded 3.264 and 2.6 respectively. These areas also showed a high $\mathrm{p}$-value of $\mathrm{p}<0.01$, indicating a confidence level of $99 \%$. In the day-time, the Jelutong Police Station sector area showed a significant hotspot area of GI_Bin $=1$ with pvalue $\mathrm{p}<0.001$. Based on the hotspot analysis, the Jelutong area shows a high-risk of home burglary as the incidence of house-break-in occurs regardless of day-time or night-time. A few main factors contributing to house-break-in in this particular area; valuable items in the house and insufficient competent guards securing the residential areas (Siti Rasidah Md Sakip and Abdullah Aldrin, 2008). 
Table 4. House-breaking hotspot in 2013

\begin{tabular}{llccc}
\hline Police station sectors & Police station & Z-Score & P-Value & Gi_Bin \\
\hline & $\begin{array}{c}\text { Day-time } \\
\text { Sector 28 }\end{array}$ & & & \\
& $\quad$ Jelutong & 6.844 & 0 & 3 \\
Sector A & $\quad$ Night-time & & & \\
Sector 2 & Sg Nibong & 3.926 & 0.000 & 3 \\
Sector 26 & Pulau Tikus & 3.264 & 0.001 & 3 \\
Sector 27 & Jelutong & 2.598 & 0.009 & 3 \\
Sector 29 & Jelutong & 1.939 & 0.053 & 1 \\
Sector 25 & Jelutong & 1.937 & 0.053 & 1 \\
Sector B & Dato Keramat & 1.935 & 0.053 & 1 \\
& Sg Nibong & 1.926 & 0.054 & 1 \\
\hline
\end{tabular}

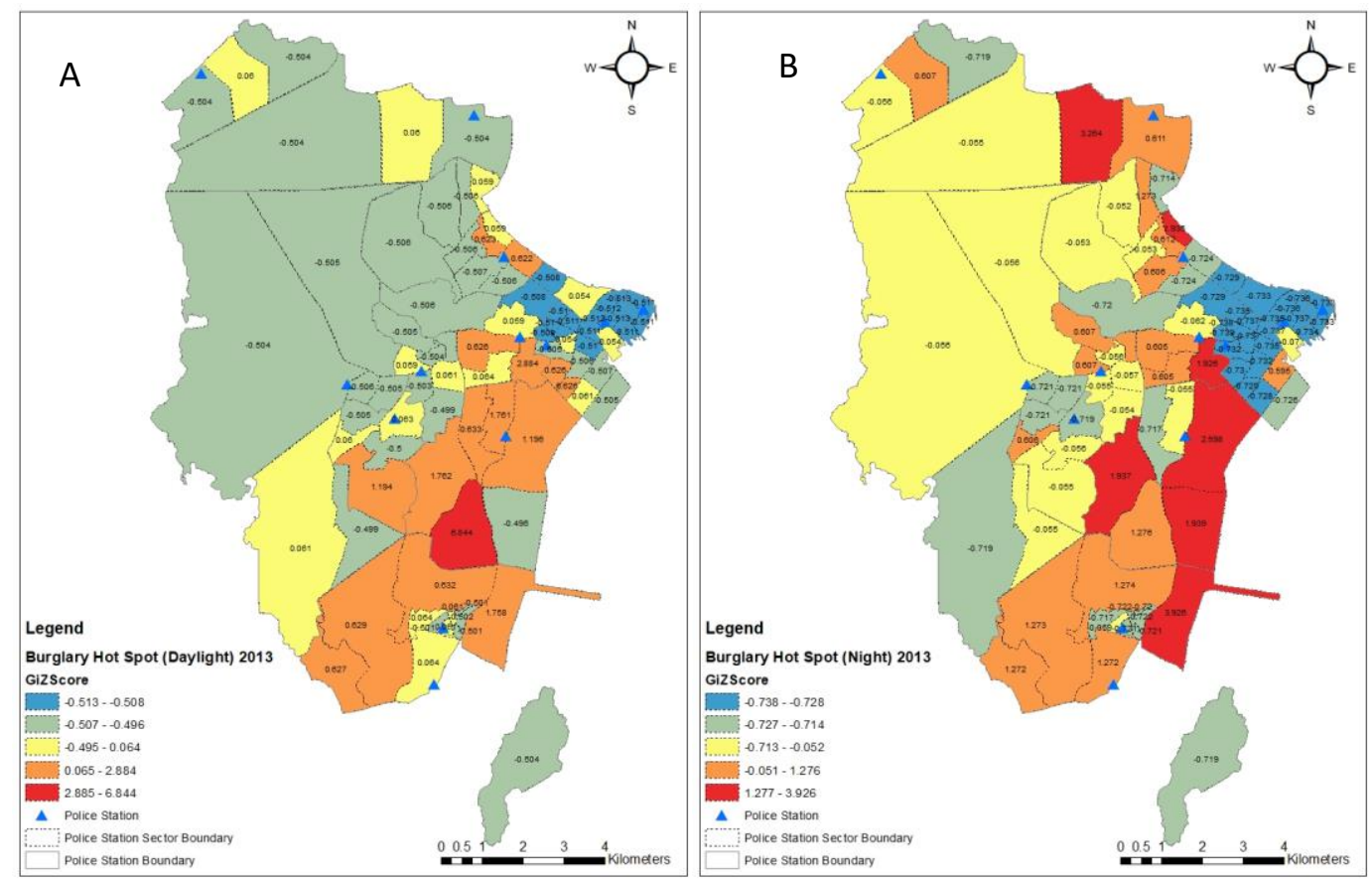

Figure 3. House break-in hotspot, 2013 (A: Day-time, B: Night-time)

The number of hotspots in 2014 increased to 19 sectors compared to 2013. Nine sectors of hotspots were identified at night-time whereas ten sectors in the day-time. The hotspots for home burglaries at night-time involved Sungai Nibong, Tanjong Tokong, Jelutong, Ayer Itam, and Dato Keramat Police stations while day-time comprises of Jelutong, Sungai Nibong, Bandar Baru, Tanjong Tokong and Dato Keramat Police Station sectors as shown in Table 5.

Sungai Nibong (Sector A) and Tanjong Tokong (Sector 1) recorded the highest hotspots with Gi_Bin = 3 during the night time. Sector A and Sector 1 have z-score values of 3.302 and 3.302 while the p-values were 0.001 for Sector A and Sector 1 was 0.001 which is highly significant with 99\% confidence level. At daytime, Jelutong (Sector 29) and Sungai Nibong Police Station (Sector A) recorded the highest Gi_Bin compared to other hot spots. The z-score for Sector 29 and Sector A were 3.640928 and 3.636675 respectively, while the p-value showed a 99\% confidence level of $p<0.001$ as shown in Table 5. Most of the house break-in hotspots in day and night time were located in the same sectors. This shows that house break-in cases in 2014 happen at any time of the day regardless of day-time or night- 
time. Additionally, there was an increase in hotspot cases which mostly happened at night compared to the other years. The changing of hotspot areas probably due to factors that influence the failure of the crime. For instance, mechanical crime control programs such as the use of keys systems, emergency sounds, closed-circuit camera monitoring by authorities or crime prevention programs have been applied in the area (Siti Rasidah Md Sakip \& Abdullah Aldrin, 2008). Figure 4 shows the house break-in hotspot cases according to the time of the incidents.

Most of the time, the house break-in cases happened when the owners were absent during the day. Usually, the homeowners went for work. Thieves are more likely to target a vacant house during the day. Thieves will monitor the house for a few days to confirm that the occupants went to work before breaking in. In addition, it is possible that thieves just knock on the front door to confirm that no one lives in the house (Kleemans, 2018).

Table 5. Home burglary hotspot in 2014

\begin{tabular}{|c|c|c|c|c|}
\hline Police station sectors & Police station & Z-Score & P-Value & Gi_Bin \\
\hline \multicolumn{5}{|c|}{ Day Time } \\
\hline Sector 29 & Jelutong & 3.641 & 0.000 & 3 \\
\hline Sector A & Sg Nibong & 3.637 & 0.000 & 3 \\
\hline Sector 23 & Jelutong & 2.429 & 0.015 & 2 \\
\hline Sector 1 & Bandar Baru & 2.426 & 0.015 & 2 \\
\hline Sector C & Sg Nibong & 2.424 & 0.015 & 2 \\
\hline Sector 28 & Jelutong & 1.825 & 0.068 & 1 \\
\hline Sector 27 & Jelutong & 1.823 & 0.068 & 1 \\
\hline Sector 3 & Tanjong Tokong & 1.818 & 0.069 & 1 \\
\hline Sector 22 & Dato Keramat & 1.817 & 0.069 & 1 \\
\hline Sector 1 & Tanjong Tokong & 1.817 & 0.069 & 1 \\
\hline \multicolumn{5}{|c|}{ Night time } \\
\hline Sector A & Sg Nibong & 3.302 & 0.001 & 3 \\
\hline Sector 1 & Tanjong Tokong & 3.302 & 0.001 & 3 \\
\hline Sector 26 & Jelutong & 2.265 & 0.024 & 2 \\
\hline Sector 28 & Jelutong & 1.753 & 0.080 & 1 \\
\hline Sector 2 & Tanjong Tokong & 1.750 & 0.080 & 1 \\
\hline Sector 23 & Jelutong & 1.749 & 0.080 & 1 \\
\hline Sector 24 & Jelutong & 1.748 & 0.080 & 1 \\
\hline Sector A & Ayer Itam & 1.747 & 0.081 & 1 \\
\hline Sector 36 & Dato Keramat & 1.744 & 0.081 & 1 \\
\hline
\end{tabular}



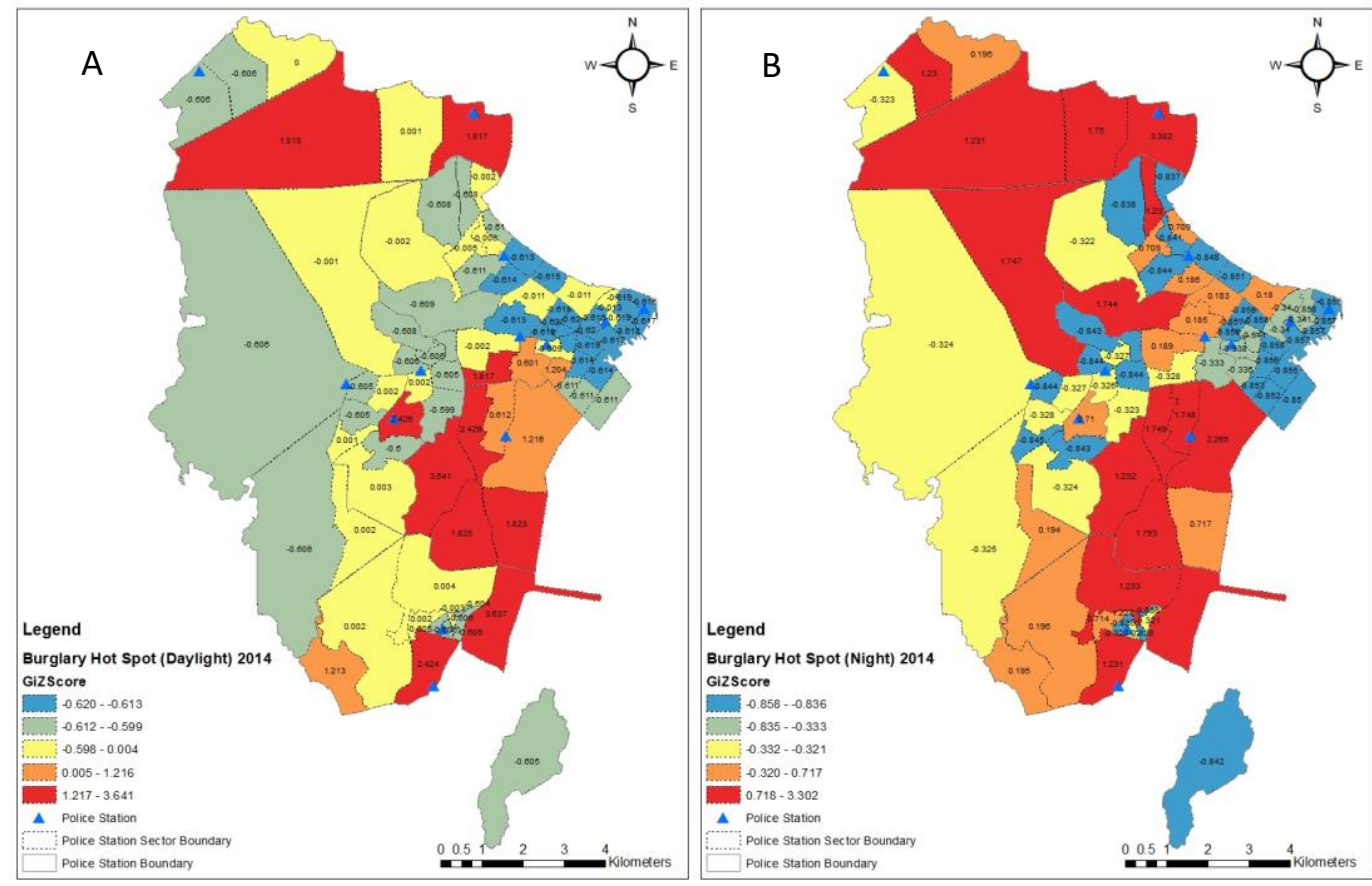

Figure 4. House break-in hotspot, 2014 (A: Day-time, B: Night-time)

In 2015, the house break-in cases showed a declining number of hotspots compared to 2014. There were 10 sectors of hotspots identified in 2015 compared to 19 in the previous years. The number of hotspots during the day-time and night-time was about five. At nighttime, Jelutong and Tanjung Tokong Police Station were involved while three sectors were identified during day-time (Tanjung Tokong, Jelutong, and Batu Feringghi Police Station) (Table 6).

Table 6. House break-in hotspot in 2015

\begin{tabular}{llrrr}
\hline Police station sectors & Police station & Z-Score & P-Value & Gi_Bin \\
\hline & Day-time & & & \\
Sector 1 & Tanjong Tokong & 4.820 & 0.000 & 3 \\
Sector 28 & Jelutong & 3.270 & 0.001 & 3 \\
Sector 23 & Jelutong & 3.270 & 0.001 & 3 \\
Sector C & Batu Feringhi & 2.489 & 0.013 & 2 \\
Sector 24 & Jelutong & 1.717 & 0.086 & 1 \\
& & & & \\
& $\quad$ Night-time & & & \\
Sector 28 & Jelutong & 3.676 & 0.000 & 3 \\
Sector 29 & Jelutong & 3.676 & 0.000 & 3 \\
Sector 26 & Jelutong & 2.690 & 0.007 & 3 \\
Sector 23 & Jelutong & 2.199 & 0.028 & 2 \\
Sector 1 & Tanjong Tokong & 2.193 & 0.028 & 2 \\
\hline
\end{tabular}

Sector 28, Sector 29 and Sector 26 in the Jelutong area recorded Gi_Bin = 3 during night-time house break-in cases. These sectors recorded high statistical value compared to the other hotspots. Sector 28, Sector 29 and Sector 26 of the Jelutong areas recorded high z-score values of 3.676, 3.676 and 2.690 respectively. These sectors showed a high confidence level of $99 \%$. The p-values for Sector 28 and Sector 29 were 0.000, while Sector 29 was 0.007 . During the day-time, three police station sectors have high statistical values which are Tanjung Tokong (Sector 1) and Jelutong (Sector 28 and Sector 23) with Gi_Bin = 3. Z-score 
values for Sector 1, Sector 28 and Sector 23 recorded were 4.820, 3.270 and 3.270 respectively with the lowest $\mathrm{p}$-value of $\mathrm{p}<0.001$. This showed that Jelutong and Tanjung Tokong areas recorded high house-breaking incidents regardless of day-time or night-time. Figure 5 showed the identified hotspot areas based on the method used.

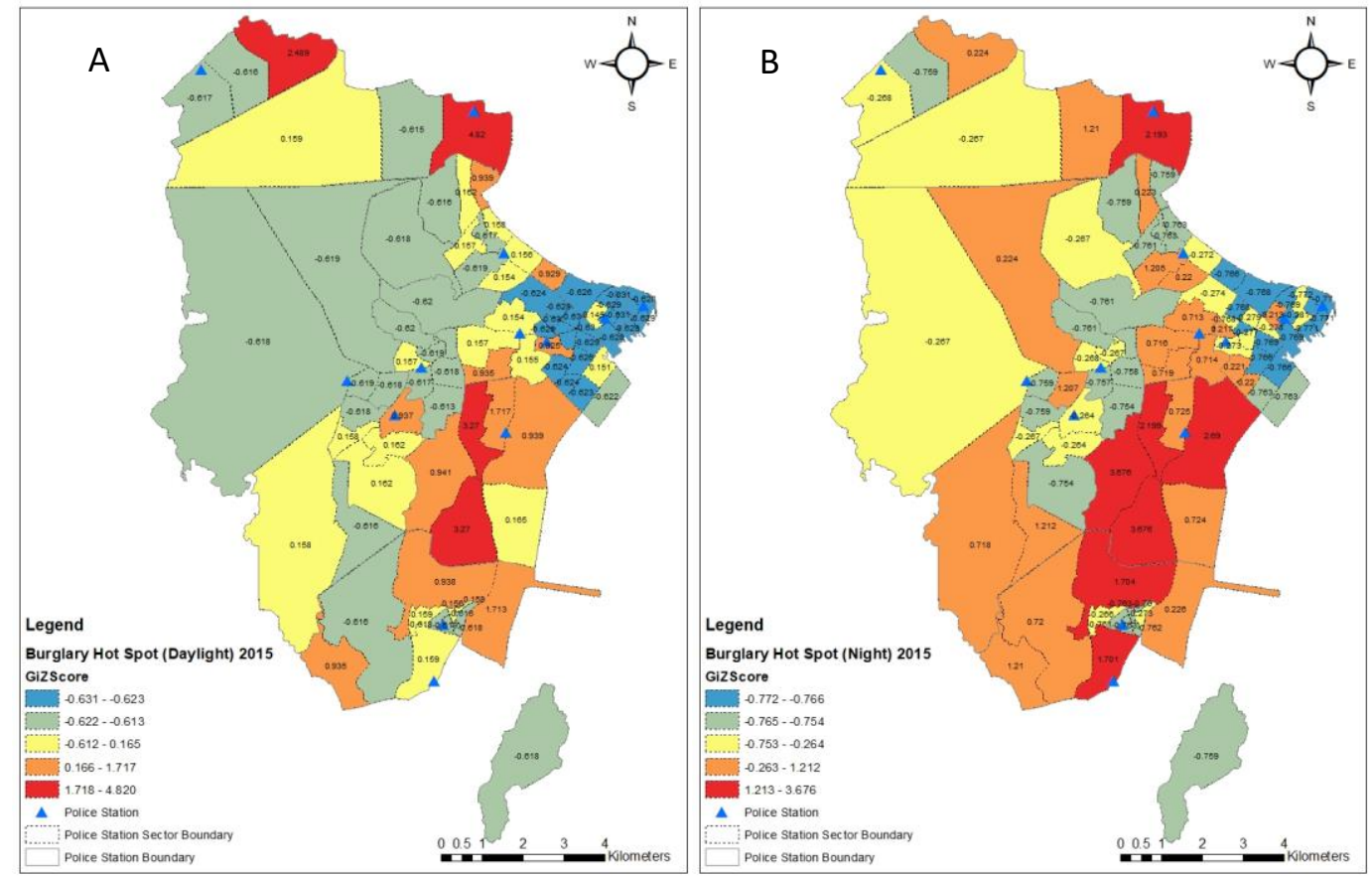

Figure 5. House break-in hotspot, 2015 (A: Day-time, B: Night-time)

The house break-in hotspot areas revealed that the residential areas were in high prevalence due to road accessibility. As shown in Figure 3 to Figure 5, the Jelutong, Georgetown and Ayer Itam areas have satisfactory road access. Previous studies also found that urban areas with major road networks provide access to criminals in and out, and are the axis that dominates crime events as facilities located along the street often suffer from armed robbery or theft. Crime hot spots are also more prevalent in the urban core such as in Akure City, Nigeria (Olajuyigbe et al., 2015).

Accessibility is essential in the process of deciding where to commit a crime. Some studies have found that areas with less accessibility may have a lower risk of being victimized and that accessibility is positively associated with theft. If road network access is poor, then house break-in activities will be difficult (Hillier, 2004).

Crime rates are also affected by proximity to highways, as highways provide quick and efficient means for criminals entering and exiting community areas. Highway patrol officers, criminologists, district attorneys, and other specialists say more and more criminals have found the road to provide potential victims with easy escape (Choate, 2015).

\section{Conclusion}

The study shows that the hotspots of home burglary are more concentrated at the residential areas with good road network accessibility. Hotpots of home burglary cases are highly concentrated in Georgetown and Jelutong is probably due to high population density and lowcost housing areas. In addition, home burglary cases occur more often at night. Night time provide safer environment setting for burglars as it has low risk to encounter someone and 
getting exposed. GIS application was able to identify hotspot of home burglary cases and help the authorities to monitor and plan an effective control measure strategy of crime prevention.

\section{Acknowledgement}

The authors would like to express our special thanks to Universiti Malaysia Sarawak for the Special Top-Down Grant (SpTDG) (F06/SpTDG/1731/2018), Royal Malaysian Police (PDRM), Criminal Investigation Department, Penang Contingent Police Headquarters, and Northeast District Police Headquarters. The contributions are gratefully acknowledged and sincerely appreciated by us.

\section{Reference}

Ahmad Tarmizi Abd Rahman, Nor-Ina Kanyo, Norizan Hj. Mohd. Nor, Norhuda Salleh, Norita Anak Jubit, Siti An-Nur Arsyi Lajimin \& Norcikeyonn Samuni. (2017). Pelakuan jenayah harta benda di kawasan hotspot di Sabah: Satu penemuan. Jurnal Komunikasi Borneo, edisi khas (Konvokesyen ke-19 UMS), 104-116. (in Malay)

Arnesson, A., \& Lewenhagen, K. (2018). Comparison and prediction of temporal hotspots maps. Retrieved from https://www.divaportal.org/smash/get/diva2:1228347/FULLTEXT01.pdf

BERNAMA. (2019, August). PDRM kaji semula elemen jenayah indeks. Retrieved from http://www.bernama.com/state-news/beritabm.php?id=1762391 (in Malay)

Boldt, M., \& Borg, A. (2017). A statistical method for detecting significant temporal hotspots using LISA statistics. 2017 European Intelligence and Security Informatics Conference (EISIC), Athens, pp. 123-126. doi: 10.1109/EISIC.2017.24.

Choate, C. (2015). A spatial statistical analysis of the effect of gentlemen's clubs on crime in the city of Los Angeles (Master thesis). Retrieved from California State University Northridge.

Department of Statistics Malaysia. (2015). Buletin Perangkaan Sosial. Retrieved from https://newss.statistics.gov.my/newss-portalx/ep/epLogin.seam (in Malay)

Department of Statistics Malaysia. (2017). eStatistic. Retrieved from https://newss.statistics. gov.my/newss-portalx/ep/epProductFreeDownloadSearch.seam

ESRI. (2005). How hot spot analysis: Getis-Ord Gi* (spatial statistics) works. Retrieved from http://resources.esri.com/help/9.3/arcgisengine/java/gp_toolref/spatial_statistics_tools /how_hot_spot_analysis_colon_getis_ord_gi_star_spatial

Hedayati, M., Abdullah, A., \& Maghsoodi Tilaki, M. (2019). The impact of the physical environmenton residents' self-rated health: A casestudy in Penang, Malaysia. Malaysian Journal of Sustainable Environment, 6(1), 109-127.

Hillier, B. (2004). Can streets be made safe? Urban Design International, 9(1), 31-45.

Kleemans, E.R. (2018). Repeat burgalry victimization: Result of empirical research. Crime Prevention Studies, 12, 53-68.

Ling Ta, T. (2016). Managing high-rise residential building in Malaysia: Where are we? 2nd Naprec Conference (pp. 1-25). Kajang, Selangor: INSPEN.

Liu, H., Zhu, X., Zhang, D., \& Liu, Z. (2019). Investigating contextual effects on burglary risks: A contextual effects model built based on bayesianspatial modeling strategy. International Journal of Geo-Information, 8(448), 2-17. 
Luo, J. (2017). Multi-spatiotemporal patterns of residential burglary crimes in Chicago: 20062016. ISPRS Annals of the Photogrammetry, Remote Sensing and Spatial Information Sciences, IV-4/W2, 193-198. https://doi.org/10.5194/isprs-annals-IV-4-W2-193-2017

Mahfoud, M., Bhulai, S., \& Van Der Mai, R. (2017). Spatial-temporal modeling for residential burglary. 6th International Conference on Data Analytics, November 12-16 (pp. 59-64). Barcelona (Spain): IARIA.

Mburu, L., \& Bakillah, M. (2016). Modeling spatial interactions between areas to assess the burglary risk. International Journal of Geo-Information, 5(4):47, 1-16.

Mohamed, A.K. (2019). Bandar bebas jenayah. Jabatan Pembangunan Bandar dan Desa Negeri Selangor. Retrieved from http://www.jpbdselangor.gov.my/keratan-akhbargalerimenu-118/440-article-keratan-akhbar.html (in Malay)

Mohd Norarshad Nordin \& Tarmiji Masron. (2016). Analisis ruangan hotspot penyalahgunaan dadah di Malaysia: Kajian kes Daerah Timur Laut, Pulau Pinang. Geografia-Malaysian Journal of Society and Space 12(5), 74-82. (in Malay)

Nandri, V. (2018). Belanjawan Pulau Pinang 2018. Retrieved from https://www.penang.gov.my/ dmedia/360024-belanjawan-pulau-pinang-2018 (in Malay)

Norita Jubit, Tarmiji Masron, Mohd Norarshad Nordin \& Danggat Chabo. (2019). Aplikasi GIS dalam mengenal pasti kawasan hot spot jenayah harta benda di Kuching, Sarawak. Geografia-Malaysian Journal of Society and Space, 15(4), 30-49. (in Malay)

Olajuyigbe, A., Adegboyega, S.A.-A., \& Adenigba, A.D. (2015). Spatial analysis of factors responsible for spread of crime activities in Akure, Nigeria, using gis techniques. International Journal of Criminology and Sociological Theory, 8(1), 1-19.

Prime Minister's Department of Malaysia. (2014). Laporan tahunan GTP. Retrieved from https://www.apad.gov.my/sites/default/files/GTP_AR2014_BM.pdf (in Malay)

Siti Norul Huda Abdullah, Farah Aqilah Bohani, Zakree Ahmad Nazri, Yasmin Jeffry, Mohammed Ariff Abdullah, Md Nawawi Junoh \& Zainal Abidin Kasim. (2018). Pengecaman kemudahan awam sekitar lokasi jenayah kormesial bersiri di Lembah Klang dan Kuala Lumpur menggunakan kaedah Gugusan K-Means. Jurnal Teknologi, 80(4), 45-53. (in Malay)

Siti Rasidah Md Sakip \& Abdullah Aldrin. (2008). Bimbang terhadap jenayah menjejaskan kualiti kehidupan manusia sejagat. Seminar Penyelidikan Siswazah Alam Bina, FSPU UiTM (Perak), Disember 2008. Retrieved from https://www.researchgate.net/publication/

262380078_Seminar_Bimbang_Terhadap_Jenayah_Menjejaskan_Kualiti_Kehidupan _Manusia_Sejagat (in Malay) 